\section{Commentary: Are the results of reimplantation of the aortic valve the same for bicuspid and tricuspid valves?}

\author{
Tirone E. David, MD
}

Reimplantation of the aortic valve was originally developed to treat patients with aortic root aneurysm and dilated aortic annulus. ${ }^{1}$ The aortic root aneurysm may have a bicuspid aortic valve (BAV) or tricuspid aortic valve (TAV). Because dilatation of the aortic annulus is frequently present in patients with incompetent BAV, de Kerchove and colleagues ${ }^{2}$ suggested that reimplantation of the aortic valve is a better approach to treat patients with BAV than conventional aortic valve repair, even in the absence of an aneurysm. Those investigators recently published the outcomes of reimplantation of the aortic valve in 440 patients (177 BAV; 76 without aneurysm), and freedom from reoperation at 10 years was approximately $90 \%$ and similar for TAV and $\mathrm{BAV}^{3}$ Other investigators have also shown that BAV had no adverse effect on the mid-term outcomes of reimplantation of the aortic valve. ${ }^{4,5}$

In this issue of the Journal, Mokashi and colleagues ${ }^{6}$ from the Cleveland Clinic published their experience with reimplantation of the aortic valve in patients with BAV and compared the outcomes with TAV using propensity score analysis. From 2002 to 2017, they operated on 607 patients, 92 with a BAV. Median follow-up for the BAV was only 2.8 years, suggesting that BAV was a more recent introduction to this type of surgery. There were 5 aortic valve reoperations for severe aortic regurgitation in the BAV group with a freedom from reoperation of $94 \%$ at 5 years and $77 \%$ at 8 years, whereas there was only one such aortic valve reoperation in the TAV group with freedom from reoperation of $98 \%$.

From the Division of Cardiac Surgery of the Peter Munk Cardiac Centre at Toronto General Hospital and the University of Toronto, Toronto, Ontario, Canada.

Disclosures: Author has nothing to disclose with regard to commercial support.

Received for publication March 2, 2020; accepted for publication March 3, 2020; available ahead of print April 9, 2020.

Address for reprints: Tirone E. David, MD, 200 Elizabeth St 4N453, Toronto, Ontario M5G 2C4, Canada (E-mail: tirone.david@uhn.ca).

J Thorac Cardiovasc Surg 2022;163:64-5

0022-5223/\$36.00

Copyright (c) 2020 by The American Association for Thoracic Surgery

https://doi.org/10.1016/j.jtcvs.2020.03.028

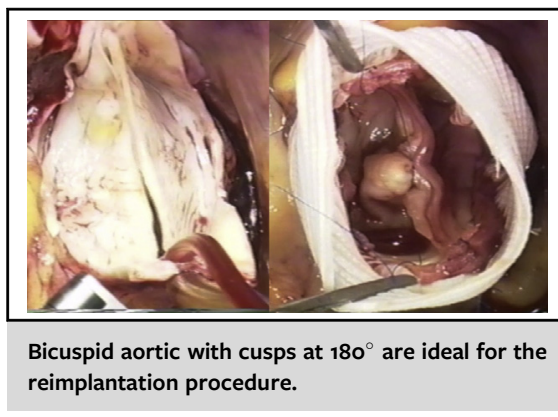

CENTRAL MESSAGE

Bicuspid aortic valves are

morphologically heterogeneous

and certain geometric configu-

rations will not provide as stable

valve function after reimplanta-

tion procedure as tricuspid

valves do.

Clearly, patients with BAV did not do as well as those with TAV.

I believe that BAV will adversely affect long-term durability of reimplantation of the aortic valve. We introduced this operation in 1989 to treat aortic root aneurysm in patients with TAV and did not use it in BAV until the year 2000. In addition, I have been selective and used it only in patients with normal cusps. ${ }^{7}$ I predict that patients with Sievers' type 0 BAV (Figure 1) will have as good longterm results as patients with TAV after reimplantation of the aortic valve. Sievers' type 1 BAV probably will have inferior results, mostly because of the heterogeneity of this subgroup. First, there is no agreement on how to reimplant this type of BAV. The group from Belgium believes that realignment of the 2 commissures to a $180^{\circ}$ is important for durability of the repair. ${ }^{8,9}$ Other investigators believe that the geometric configuration of the cusps should be maintained during reimplantation of the BAV ${ }^{10,11}$ Longer follow-up with objective assessment of valve function is needed to determine the usefulness of reimplantation of the aortic valve in Sievers' type 1 BAV and how to align the commissures inside the graft. Aortic stenosis is rare after reimplantation of a TAV during the first 2 decades of follow up, but it is not in BAV. ${ }^{12}$

Finally, the long-term outcomes of aortic valve replacement or a Bentall procedure with a bioprosthesis must be weighed against the risk of reoperation after reimplantation of a BAV. The results of aortic valve replacement with 


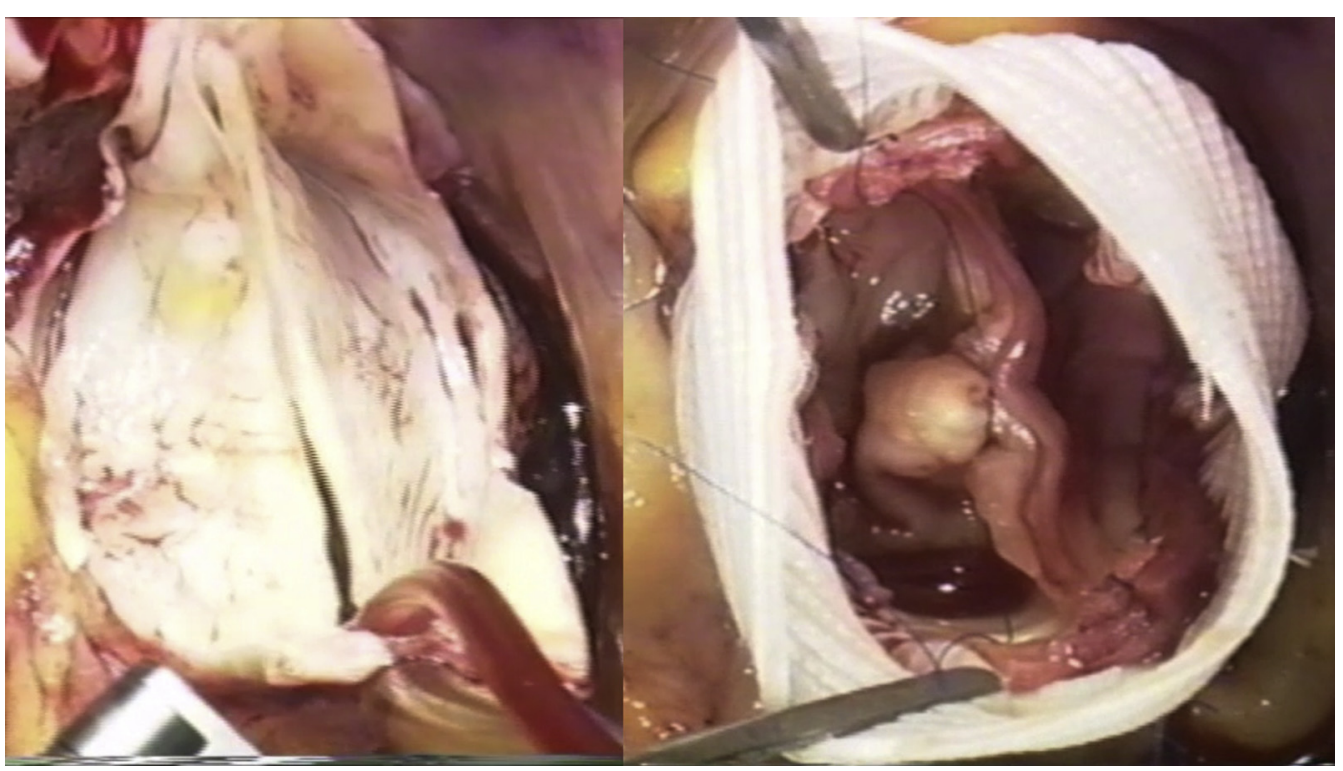

FIGURE 1. Bicuspid aortic with cusps at $180^{\circ}$ are ideal for the reimplantation procedure.

Hancock II bioprosthesis ${ }^{13}$ are associated with lower reoperation rate for valve failure than the results reported by Mokashi and colleagues ${ }^{6}$ for reimplantation of BAV. In addition, since the advent of transcatheter aortic valve implantation into failed bioprostheses, it is probably simpler and safer to deploy a new valve inside a failed bioprosthetic valve than in a reconstructed aortic root with a BAV.

\section{References}

1. David TE, Feindel CM, Bos J. Repair of the aortic valve in patients with aortic insufficiency and aortic root aneurysm. J Thorac Cardiovasc Surg. 1995;109:345-52.

2. de Kerchove L, Boodhwani M, Glineur D, Vandyck M, Vanoverschelde JL, Noirhomme $\mathrm{P}$, et al. Valve sparing-root replacement with the reimplantation technique to increase the durability of bicuspid aortic valve repair. J Thorac Cardiovasc Surg. 2011;142:1430-8.

3. Mastrobuoni S, de Kerchove L, Navarra E, Watremez C, Vancraeynest D, Rubay J, et al. Long-term experience with valve-sparing reimplantation technique for the treatment of aortic aneurysm and aortic regurgitation. $J$ Thorac Cardiovasc Surg. 2019;158:14-23.

4. Bavaria JE, Desai N, Szeto WY, Komlo C, Rhode T, Wallen T, et al. Valvesparing root reimplantation and leaflet repair in a bicuspid aortic valve: comparison with the 3-cusp David procedure. J Thorac Cardiovasc Surg. 2015;149(2 suppl):S22-8.

5. Kvitting JP, Kari FA, Fischbein MP, Liang DH, Beraud AS, Stephens EH, et al. David valve-sparing aortic root replacement: equivalent mid-term outcome for different valve types with or without connective tissue disorder. J Thorac Cardiovasc Surg. 2013;145:117-26.

6. Mokashi SA, Rosinski BF, Desai MY, Griffin BP, Hammer DF, Kalahast V, et al. Aortic root replacement with bicuspid valve reimplantation: are outcomes and valve durability comparable to those of tricuspid valve reimplantation? J Thorac Cardiovasc Surg. 2022;163:51-63.e5.

7. Ouzounian M, Feindel CM, Manlhiot C, David C, David TE. Valve-sparing root replacement in patients with bicuspid versus tricuspid aortic valves. $J$ Thorac Cardiovasc Surg. 2019;158:1-9.

8. Nawaytou O, Mastrobuoni S, de Kerchove L, Baert J, Boodhwani M, El Khoury G. Deep circumferential annuloplasty as an adjunct to repair regurgitant bicuspid aortic valves with a dilated annulus. J Thorac Cardiovasc Surg. 2018; 156:590-7.

9. de Kerchove L, Mastrobuoni S, Froede L, Tamer S, Boodhwani M, van Dyck M, et al. Variability of repairable bicuspid aortic valve phenotypes: towards an anatomical and repair-oriented classification. Eur J Cardiothorac Surg. February 20, 2019 [Epub ahead of print].

10. Siki MA, Habertheuer A, Bavaria JE, Komlo C, Hunt M, Freas MA, et al. Two different geometric orientations for aortic neoroot creation in bicuspid aortic valve repair with root reimplantation. J Thorac Cardiovasc Surg. August 30, 2019 [Epub ahead of print].

11. Kari FA, Kvitting JP, Stephens EH, Liang DH, Merk DR, Fischbein MP, et al. Tirone David procedure for bicuspid aortic valve disease: impact of root geometry and valve type on mid-term outcomes. Interact Cardiovasc Thorac Surg. 2014 19:375-81.

12. David TE, David CM, Feindel CM, Manlhiot C. Reimplantation of the aortic valve at 20 years. J Thorac Cardiovasc Surg. 2017; 153:232-8.

13. Une D, Ruel M, David TE. Twenty-year durability of the aortic Hancock II bioprosthesis in young patients: is it durable enough? Eur J Cardiothorac Surg. 2014;46:825-30. 